\title{
SEMIOTIC ANALYSIS OF SATIRE MEME CONNECTING WOMEN'S IDENTITY IN BRILLIO NET
}

\author{
Rr. Astri Indriana Octavita;Yulia Sofiani Zaimar \\ Program of English Education, Faculty of Language and Art, University of Indraprasta PGRI \\ Jalan Nangka No. 58C Tanjung Barat, Jagakarsa, South Jakarta 12530 \\ mrs.astriindriana@gmail.com, oleel27@yahoo.com
}

\begin{abstract}
This research shows that the origins of the confusion surroundings the theoretical status of cyber technology memes today could be found in culture. Those memes later developed in memetics, the science of memes. Meme is a common way for individuals to communicate online. Internet users often use memes to reply to each other on social networking sites or other online forums. This research argues that memes are successfully used for communication purposes because certain memes (specifically image macros) are essentially speech acts and are also understood as being speech acts by internet users. When creating a meme, choices are made concerning the specific semiotic resources to be used and the internet community then interprets these resources to facilitate communication between the meme creator and the internet community. Memes can be recreated for different purposes and therefore it is possible to group memes under already existing speech acts and speculate about the ways in which these might correspond to speech acts in the future.
\end{abstract}

Key words: memes, media, women, body, semiotic

\begin{abstract}
ABSTRAK
Penelitian ini menunjukkan bahwa asal mula dari status meme pada teknologi cyber saat ini dapat ditemukan dalam suatu budaya. Meme kemudian dikembangkan dalam ilmu memetika. Meme adalah cara untuk berkomunikasi yang digunakan oleh orang-orang secara online. Pengguna internet sering menggunakan meme untuk membalas satu sama lain di situs jejaring sosial atau forum online lainnya. Penelitian ini berpendapat bahwa meme berhasil digunakan untuk tujuan komunikasi karena meme tertentu (khususnya gambar makro) pada dasarnya adalah dipahami sebagai tindak tutur oleh pengguna internet. Ketika membuat meme, pilihan dibuat mengenai sumber semiotik spesifik yang akan digunakan dan komunitas internet kemudian menafsirkan sumber daya ini untuk memfasilitasi komunikasi antara pencipta meme dan komunitas internet. Meme dapat diciptakan kembali untuk tujuan yang berbeda dan karena itu memungkinkan bahwa kelompok tindak tutur dari meme yang sudah ada dan spekulasi tentang cara-cara yang mungkin berhubungan dengan tindak tutur di masa depan.
\end{abstract}

Kata Kunci: meme, media, perempuan, tubuh, semiotik 


\section{INTRODUCTION}

Nowadays, the use of internet in Indonesia has increasingly developed from year to year. Those internet contents have influenced people's life, usually, when the content deals with real-world issues, like gossiping artists, or even politics. One of the products of those internet technology contents is meme. The internet meme refers to the phenomenon of content or concepts that spread among internet users. By seeing the use of internet and social media, grown by the Indonesians, would create a new phenomenon among its users. This phenomenon, for example, is the creativity of the creation of memes, which can then spread quickly in the internet world, and is commented on social media.

Memes are considered a new way to combine many things, such as creativity, message, and humor in the media culture. Memes are usually envolved through comments, imitations, parodies, satire, and even through related news in other media. This research would like to describe themes, implication, and language aspects in humor discourse in memes in online media. Indeed, nowadays, there are many critics are provided, based on public disappointments, shown in an online social media. Those memes become viral, by spreading ideas and cultures phenomenon in person via online to criticize political issues that are more understandable in society.

Comparing to media hacking and making hoax, the viral of meme would be considered, as the greatest to reconstruct meanings inside, because it could create a new discourse in social media for criticizing something. The advance of cyber media existence is a part of communication technology, which has brought the huge power to change the way humans to get interaction. A meme is considered as a stuff, bringing cultural ideas and symbols, which can be delivered from someone's mind to another through writing or picturing, gestures or rituals phenomenon.

In creating meme, there are many messages that can be implied, including political or even gender and sexuality. Like advertisment, meme can be read, although it only provides a picture. In human's communication natural process, instead, there will always be "voice" to distract the contents of messages. This can be explained with a communication voice model. Although memes are provided in cyber media, those have totally different shape with hoaxing and hacking.

The researchers are interested in doing the research on some memes provided in Google. The memes become the main issue for them could be read, although they do not provide any single word. Based on all those information, the researchers would like to choose semiotic theory to investigate the satire in cyber memes. The reserchers will not use all memes inside, instead of choosing only some memes which connect to women's body. As for data analysis, the researchers will connect the semiotic theory and feminist theory.

Semiotics is the theory of sign systems. Instead, it has been provided, that every sign system in society belongs to the domain of Semiotics. Semiotic studies could attract to anyone, is interested in signs at large. At present, however, the attempts to address every instance of Semiotics to the general theory of sign systems have strangely widened the scope of Semiotics.

Based on Saussure (2002), a sign can be provided in a word, a sound, or a visual image, stands for a thing. This sign has two components: the signifier (the word, the sound, or image) and the 
signified (the meaning or the concept the signifier represents). Any kind of text can represent something and the internet memes are the examples of the texts that are provided with signs, both visual and linguistic arrangement, making those memes to be seen as great objects for semiotic analysis.

The Saussure's theory was followed by Roland Barthes. In Barthes' theory, following Saussure, explained that the concepts of language, or the part of the semiological system which is agreed upon by society, and speech, or the individual selection of symbols, to semiological systems. The application of these concepts can be applied to the semiological study of the food system. By using a semiotic Saussure, continuing Barthes, will guide sign systems in this memes' research. This research would examine the contributions of women's identity sign. Barthes, translated as Mythologies, reworks Saussure's theory of the sign and of signification. He is not, however, interested in the linguistic sign, as in the application of linguistics to the non-verbal signs that exist around us in our everyday life. In this case Barthes implies

(https://ceasefiremagazine.co.uk/intheory-barthes-2/).

There are three levels in Semiotics, they are the sign, the signifier and the signified. Examples of signs: bouquet of roses signifying passion; black pebble signifying death. Sign in language (Saussure): the signifier is the acoustic form of the word, the signified is the mental concept, the word itself is the sign as a sum of both. Terms: the signifier in myth is called "form," the signified "concept". This "form" already uses a fully meaningful sign "inherited" from culture (so two levels of meaning or signification).

Barthes (2001), in his Mythologies, is continuation of
Saussure's semiotical system, by separating two kinds of significations, making Saussure's sign system as the first order, and the mythological system as the second order. Barthes used the term denotation for the first order of signification that refers to the literal or clear meaning and connotation for the second order of connotation which refers to the additional cultural meanings.

Talking about myth, according to Barthes (2001), "It is a representation of the dominant ideologies of our time". Barthes attempts to unravel the layers of meaning that lie behind seemingly innocuous everyday texts that are defined as one of the early formulations that expanded this notion to include any aspect of daily life with the potential to signify meaning (in the same way as a conventional linguistic sign. In short, by using myths, it would deeply show the hidden ideological functions, this implies that contrary to Saussure's concept of the sign, myths are never arbitrary; instead, they are motivated. To the researchers of myths, the signified of connotative myths is hidden meaning, making the myth a command or a statement of fact which demands no explanation at all. Making a myth appear as the way a text aims for the producer of myths.

In creating a myth, the reseachers should see the problems as 'the way it is', that could make the aim of those as the producers of myths. This research would involve a women's identity theory, which related to semiotic system. The researchers aim to use Kristeva's theory, because Kristeva's works on text, including the presemiotic, continues to positive support from critics of a no less feminist. Instead, Kristeva's example in her writing, seems has placed her positions both. Outside feminism, Gills, et. al. (2004:72) would explain that: 
"Kristeva's thought is peculiar: it is transparent enough that it tends to be reduced very quickly to a set of bipolar opposites by her critics (and thereby criticized as being everything from ultraanarchistic to ultraconservative); but at the same time, it is opaque enough to be uncritically idealized by her most fervent admirers."

The choosing of Kristeva's theory because her thought was following semiotics Barthes' theory. She developed the notion of the 'jouissance of the text', the text as jouissance, especially as found in modern avantgarde literature, in her book Le Texte du roman. Kristeva's critics on feminists (1977:6) in that book told as follows:

"Apparent avoidance of the traditional or political roles of feminism (in statements such as while a certain feminism takes its pouting and its violation for protest and perhaps even for dissidence, genuine feminine innovation... will not be possible until we have elucidated motherhood, feminine creation, and the relationship between them."

For Kristeva, there is no specifically female text or writing, but only 'texts about women' (Gross, 1990). Kristeva's theory's background is about the way Kristeva's thought and concept, in helping to analyze the gendered aspects of the aesthetics and literary practices of symbolism. Moreover, Kristeva's thinking makes many researchers to distinguish the specific atmosphere, and many practices create for those researchers. According to Kristeva (1977), relating to her contemporary feminist critics, told that feminist's theory would provide analytical tools and new viewpoints for reading women writers' strategies in the gendered and the concept of women's beauty discourse.

In Gross' book (1990:49), her theory was explained:

"Kristeva builds her understanding of creativity and the creative process by using the central concepts of semiotic and symbolic. In general, these concepts refer to the two orders that participate in the constitution of the subject, production of discourse, and regulation of social relations."

By reading that book, it can be explained that, in her book, Kristeva would explain the concept of women's identity, by using semiotic. Her explanation points to the development of the sign, getting from women's body. Those signs cold also provide in the texts, by seeing syntax and to grammatical and social problems, told that women's identity is created by social concept about women.

\section{METHOD}

In this research, the researchers would like to use qualitative method. According to Setiawan and Saryono (2010), qualitative research is a study used to investigate, to find, to describe, and to explain the quality or privilege of social influences that cannot be explained, measured or described through a quantitative approach. In this research, the researchers use the qualitative method to relate the memes and semiotics, worked together to get the interpretation in the memes. Therefore, the researchers would find the deep meaning behind the memes.

Actually, the purpose of this research is to look for the construction of social meanings contained in several memes. The researchers would take women, who have fat body, hits in social media as the object of their research. This research would be explained, by 
looking at relationships that exist in signs, objects and interpretations. The sign that would be investigated in the research is taken from several memes. The problems, that would be investigated, as follows: the image, appearance, shape, color in the memes of women, which have the theme of women, who have a disproportionate body that is the object of this research.

Moreover, the element of the object is the meaning of the signs that exist in the meme of women who have large bodies, while the interpreters are the attitudes and thought patterns of creators. In addition, the primary data obtained from the results of this study were adjusted, based on research needs. Furthermore, data processing and descriptive analysis are carried out by explaining, describing and comparing information obtained with theories and concepts that have been set and the results of previous studies to enrich the discussion of the results of the study.

\section{RESULTS AND DISCUSSION}

In this part, the researchers would like to show, that in every media, there are many discourse, related in society. In this research, the researchers would like to connect some memes, which are related to women's identity. The researchers aim to use semiotic theory, which comes from Roland Barthes. In addition, the researchers would also use qualitative method to analyze those memes. The memes used here are taken from Brillio.net.

This research aims in the world of entertainment, which is now equipped with very excellent tools, women function predominantly as forming images and signs of various commodities. Every commodity is a spectacle. In society, a woman's body is an object to be enjoyed, which functions as a tool for selling commodities - or the body itself as a commodity, which has a very central role.

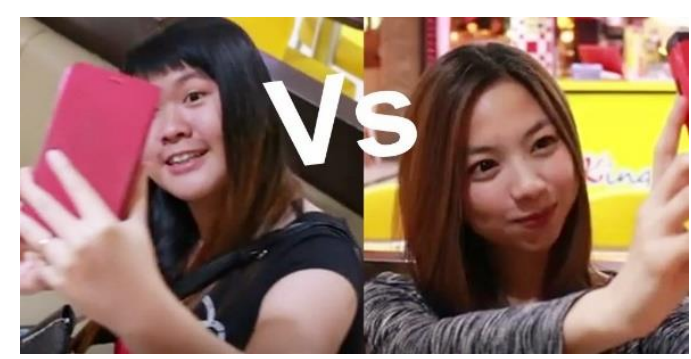

Figure 1

Like the meme above, making the body as a spectacle, for some women is a bridge or a shortcut to enter the popular world, to gain popularity, to pursue a lifestyle, and to achieve material satisfaction. In this condition, women without realizing they are actually socially constructed to be in the marginal world, namely the world of objects, the world of image, and the world of commodities. Because the image of women in the spectacle community is like that, often mass media, especially TV and or social media, is accused of only showing women as charmers. In the picture above, it can be analyzed that the meme is like making a body on a woman's body, such as a woman with a beautiful face vs. a woman with a mediocre face or a white woman vs. a black woman. In the long run, all those things, were brought up by fashion, or beauty queens competition.

It cannot be denied that memes in the media contain gender bias. existing memes discriminate against women through representation, in visuals and texts. The most prominent representation and source of debate among various groups is representation that highlights the comparison, where the element of female sexuality is highlighted when he becomes a messenger. As a cultural product, the existence of memes will never be 
separated from the institutions that produce them. This is explained in a statement by Strinati (2007:5), which states that "This institution is certainly part of a society that has a set of values believed to be the heritage of its ancestors in the form of culture". The representation they produce is by a little meme that will reflect their ideology related to the condition of an ideal society. These discursive practices ultimately produce, reproduce or even perpetuate discourse that supports a dominant force that produces 'common sense' for people who consume it, like meme that shows below:

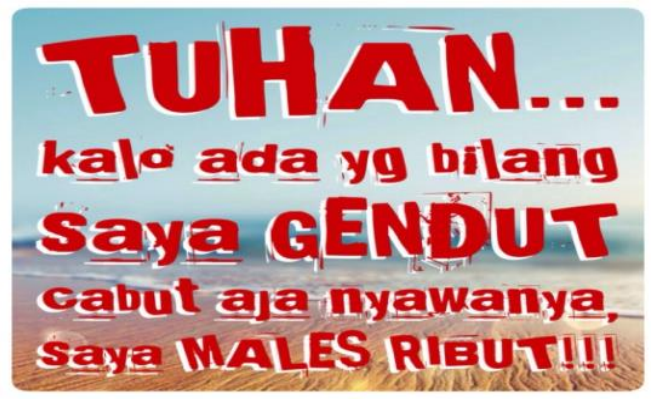

Figure 2

In the sentence described in the meme, told "Kalo ada yang bilang saya gendut", it can be represented as a sentence pronounced by a woman. The meme picture depicts someone inspiring in social networking media, most of which are also carried out by women, and in connotation meaning makes them commit to be a victim. Owners of profiles on social networks actively use their profiles as a place to express themselves. From the meme above, online identity or internet identity, especially for women, is a social identity made by internet users in a community or online website. This can also be realized as the construction of online presentations.

From the analysis above, it can be said that, through various displays of media creating a touch of sensuality, the ideal appearance of the model brings women in dreams and pseudo reality as desired by the owners of capital and workers who are based on patriarchal values. Through the role of media, it creates a longing for seeking selfidentity based on the body and further deepens the stereotypical representation of women. The words "If anyone says I am Fat, pull out his life, I am lazy for thousands", can prove that, creatures that often make a fuss about their body shape are women. They always want to look perfect, if they appear in the midst of society.

Based on the memes about women's body above, in the context of consumer culture, the body is described as a body that consumes all forms of commodities offered by the capitalist industry and simultaneously, the body also becomes one of the commodities that can be traded. The meaning of the body as a commodity cannot be separated from the rules and values that apply in consumer culture. Featherstone (1982) explains that "In consumer culture, appearance is the main factor in determining of selling value because the body is believed to be a means to enjoy pleasure and self-expression so that it reflects one's identity". According to the statement, it can be explained that the meaning of a woman's body in consumer culture is never separated from the regulation of patriarchal ideology, the ideology of consumerism and gender ideology, when there is a demand for women in treating their bodies with a series of conventions that are different from the conventions governing men. In consumer culture, a woman's body is constructed through a set of norms, resulting in a hegemony over the concept of a beautiful body.

In the meme on Brilio.net, it can be seen that there is a construction of the beautiful body of a woman. The 
awareness of an ideological hegemony is not equivalent to one's actions to reject the hegemony because it is in that order that one can rationalize its existence. Awareness also has an impact on a person's ability to take an active position by using the rules that apply to the ideological hegemony for self-interest. The presence or absence of awareness that body beauty is a construction determines the position taken. The unconsciousness will bring someone in a position as an object that is hegemony by regulations that are enforced and trap a person in conditions that are determinant and despair caused by the inability to change conditions as seen from the presence or absence of female selfconfidence. In these memes, women's bodies are also linked to gender roles that traditionally place women's bodies in domestic space versus men's bodies in public spaces.

The body is also treated as a commodity that has selling value following the applicable conventions. The awareness of the body as a commodity puts women in a position as subjects and objects simultaneously. As subjects, women in the memes above consciously use various body trimmings and consume various products to increase their selling value which depends on the appearance of the body. In culture in the public sphere, feminine markers are increasingly emphasized in women's bodies so that femininity is identical with a preening body. The body of preening will triumph in public space, because this is where the body is exhibited to be seen and looked at other bodies in an arena of contestation. The body that is in the marginal domestic space due to show-showing and viewingview activities is not possible. Traditionally the female body is always regulated by many rules that repress, then the transition from traditional culture to modern.

In memes it can be analyzed that, women are conditioned to rely on other people's judgment when they want to measure or to assess their experiences around body problems. Placed in the current socio-culture, which contributes to the structure of women's experience of the body, it is a high social demand to prioritize aspects of physical appearance as a source of values and meanings of the body. Social demands to prioritize aspects of physical appearance are accompanied by a process of uniformity to criteria that are benchmarks for ideal physical appearance.

Based on the memes, female body has been exploited in various mass media, but many of us are often not aware of it. Douglas (1992) sees the body system as a symbol system of everything. He divided the body into two, namely the self (individual body) and the society (the body politics). The body politics shapes how the body is physically felt. The physical experience of the body is always modified by known social categories which consist of certain views from the community.

\section{CONCLUSION}

From all the analysis above, it can be concluded that women's bodies are always present in the pull of regulation of several ideologies. Women's body in the context of consumer culture is a body that has the authority to choose how the body wants to be displayed, but that authority is not value-free, because the body remains in the cultural hold. Related to the relationship between body discourse and power, contemporary feminists have criticized it. They see discourse on the body not in the interests of science but in the political tendencies that arise in relations between sexes. Social change 
often presses and encourages science to produce empirical and genetic evidence to support political policy. Studies of the body, especially the female body, are important because of the content and political interests that are there.

Through a message in the meme above seems to confirm stereotypes against women, indeed. Findings regarding the description of the female figure the researcher found in the memes above could be told as the stereotype of women, patriarchal culture, and gender roles still attached to the paradigm of all individuals. So that these three things categorize women with men, and regulate how a woman must look, not even have the freedom to determine her own weight within the scope of her gender.

The body is the main target of consumption, and thus is getting closer to the danger of exploitation. The body is cultured and worshiped in its function as a commodity in social transactions, and is often treated as an "object" just like that. It can be changed in various ways if it feels unsatisfactory and accepts various insults if it is not beautiful. The body may be discussed and exhibited in various private and public spaces, but the outward appreciation given to it is often not based on a noble meaning of human body itself.

\section{REFERENCES}

Barthes, R. (2011). https://ceasefiremagazine.co.uk/in -theory-barthes $\left(30^{\text {th }} \quad\right.$ December 2018)
Barthes, R. (2001). "Photography and Electoral Appeal" Mythologies. The Norton Anthology of Theory and Criticism. New York: W.W Norton \& Company.

Douglas, M. (1992). Risk and Blame, Essays in Cultural Theory. (Routledge).

Featherstone, M. First Published September 1, 1982, The Body in Consumer Culture, https://doi.org/10.1177/02632764 8200100203

Gills, S., et al. (eds.). (2004). Third Wave Feminism (C) Palgrave Macmillan, a division of Macmillan Publishers Limited.

Gross, E. (1990). The Feminist Movement \& the Question of Equality. The University of Chicago Press on behalf of the Northeastern Political Science Association.

Kristeva, J. (1977). Polylogue, Seuil. London: Routledge

Saussure, F. de (2002a). Écrits de linguistique générale. Edited by $S$. Bouquet \& R. Engler, assisted by A. Weil. Paris: Gallimard. English translation, Writings in general linguistics by $C$. Sanders and $M$. Pires, with the assistance of $P$. Figueroa. Oxford and New York: Oxford University Press.

Setiawan, A., \& Saryono. (2010). Metodologi Penelitian kebidanan. Nuha Medika: Jakarta.

Strinati, D. (2007). Popular Culture: Pengantar Menuju Teori Budaya Populer. Penerbit Jejak: Bandung. 